\title{
DA PRIMEIRA QUADRA AO CALÇADÃO: NARRATIVAS SOBRE A PEDESTRIANIZAÇÃO DO CENTRO DE SANTA MARIA (RS)
}

\author{
FROM THE PRIMEIRA QUADRA TO THE CALÇADÃO: \\ NARRATIVES ABOUT THE PEDESTRIANIZATION OF DOWNTOWN SANTA MARIA (RS)
}

\author{
Filipe Bassan Marinho Maciel \\ Daniela Marzola Fialho \\ Décio Rigatti
}

\section{Resumo}

Este trabalho investiga as diferentes narrativas suscitadas pela implantação de um calçadão no centro de Santa Maria, interior do Rio Grande do Sul em 1979. Analisaram-se o discurso e as ações de um conjunto de atores sociais, a partir da perspectiva da História Cultural, tendo como fontes uma entrevista e reportagens de jornal. Os moradores da chamada Primeira Quadra foram os que se mostraram mais contrários à sua transformação em calçadão. Já a Prefeitura, o arquiteto responsável pelo projeto, os comerciantes e os usuários do espaço apresentaram discursos alinhados em torno de um objetivo comum: construir a imagem de um centro mais humano e moderno, do mesmo modo como cidades maiores estavam fazendo.

Palavras-chave: Calçadão. Desenho urbano. Paisagem urbana. História Cultural. Circulação de pedestres.

\section{ABSTRACT}

This paper investigates the different narratives raised by the implementation of a pedestrian-only street in Santa Maria downtown, in the state of Rio Grande do Sul in 1979. The discourse and actions of a group of social actors were analyzed from the perspective of Cultural History, having as sources an interview and newspaper reports. The residents of the so-called Primeira Quadra were the ones who were most opposed to its transformation into a pedestrian-only street. The City Hall, the architect responsible for the project, the merchants, and the users of the space presented discourses aligned around a common goal: to build the image of a more human and modern downtown, in the same way as larger cities were doing.

Keywords: Pedesrian-only street. Urban design. Urban landscape. Cultural History. pedestrian circulation. 


\section{INTRODUÇÃO}

Considerando-se a cidade como um espaço onde há disputa de interesses, frequentemente projetos urbanos suscitam o conflito entre diferentes atores sociais. Um indivíduo, uma classe social, um grupo social ou até mesmo instituições são atores sociais quando representam algo para a sociedade, encarnando uma ideia, uma reivindicação, um projeto, uma promessa ou uma denúncia (SOUZA, 1984). Iniciativas de pedestrianização, isto é, de priorização dos pedestres no acesso aos espaços públicos, costumam gerar reações de alguns setores da sociedade. Por exemplo, quando o prefeito Jaime Lerner inaugurou, em 1972, no centro de Curitiba, o primeiro 'calçadão' (termo popular para 'via exclusiva de pedestres') do país, a aceitação não foi unânime. Conforme relatos, alguns motoristas planejaram avançar com os carros sobre o novo espaço público no dia de sua inauguração (WILLE, 2018), como reação à restrição de seu ir e vir motorizado. Somente após algum tempo de adaptação dos usuários, o intervenções semelhantes em outras cidades.

Nesse intuito, este trabalho questiona: como esses projetos pioneiros de pedestrianização foram percebidos nas cidades do interior do Brasil? Isto é, que julgamentos, interpretações e narrativas foram suscitados frente a essas intervenções no espaço público? O problema ainda é atual, visto que a sociedade encontra-se na terceira fase da modernidade, cujas principais características socioantropológicas são a individualização, a racionalização e a diferenciação social, que tendem a influenciar nas formas de ocupação do território (ASCHER, 2010). No Brasil, ao mesmo tempo que as relações sociais estão cada vez menos voltadas ao bem-estar coletivo, ocorre um processo de valorização de espaços privados em detrimento dos espaços públicos. Os símbolos mais fortes desse fenômeno são os circuitos de consumo exclusivo, como shoppings centers e condomínios fechados, dotados de áreas próprias de lazer (SERPA, 2007).

Essa conjuntura, associada à priorização da circulação urbana motorizada ao longo do século XX, retoma a relevância da dis-

cussão sobre o papel dos espaços públicos na promoção da qualidade de vida urbana. Hoje, abordagens de planejamento urbano baseadas na dimensão humana defendem a oferta de mais espaços públicos qualificados para pedestres, a fim de se obter cidades mais sustentáveis, animadas e seguras (GEHL; SVARRE, 2017; PROJECT FOR PUBLIC SPACES, 2020). Projetos alinhados a essa agenda têm proposto desde o equacionamento democrático do espaço da rua (por meio de ruas completas ou vias compartilhadas) até a demolição e/ou pedestrianização de grandes estruturas viárias (como o antigo Elevado da Perimetral no Rio de Janeiro e o Elevado Presidente João Goulart - 'Minhocão' - em São Paulo, respectivamente). Entretanto, esses projetos enfrentam as mais diversas resistências para sua implantação, expondo a necessidade do diálogo para alinhamento de diferentes interesses.

Nesse sentido, a perspectiva histórica de estudos de caso pode contribuir criticamente, elucidando os pontos comuns presentes nos juízos de valor da sociedade relativos à pedestrianização dos centros urbanos. Propõe-se, portanto, como objeto empírico a primeira quadra da Rua Dr. Bozano, um dos espaços livres mais simbólicos do centro de Santa Maria (RS), transformado em calçadão em 1979. O trabalho tem como objetivo identificar as sensibilidades relativas à obra externadas pela sociedade em seus discursos (narrativas) ou ações. Em função disso, o trabaIho ampara-se em questões e métodos trazidos pela História Cultural.

\section{Referencial Teórico}

Com o lançamento do Ford Modelo $T$ em 1908, iniciou-se nos Estados Unidos uma era de acesso generalizado da população aos automóveis, vistos como alternativa ao transporte público e ao ato de caminhar (KEELER; BURKE, 2010). Nos anos 1950, uma nova concepção do espaço-tempo foi consolidada a partir da aceleração do tráfego urbano, que passou a demandar a adaptação da estrutura física da cidade para comportá-lo. Bairros inteiros, considerados decadentes, começaram a ser demolidos, abrindo caminho para a reurbanização e a construção de vias expressas 
(BERMAN, 1986). O rápido crescimento do número de veículos em circulação começou, então, a ser percebido como uma ameaça à qualidade de vida urbana, mobilizando setores da sociedade (MEHTA, 2013). As críticas de Jane Jacobs apresentaram um novo valor social para as zonas mistas, densas e aparentemente 'confusas' das cidades: suas ruas e calçadas animadas seriam os verdadeiros indicadores de uma vida urbana sustentável (JACOBS, 2000).

Paralelamente, o estabelecimento do desenho urbano como campo de conhecimento próprio, também nos anos 1950, trouxe vários avanços na teoria de projeto, enfatizando a dimensão humana do espaço urbano e o papel social e cultural das ruas. Vias exclusivas para pedestres - ou 'calçadões' - surgem, então, para compensar a 'invasão' dos automóveis nos centros urbanos (MEHTA, 2013). Enquanto espaço público, o calçadão pode oferecer oportunidades para atividades diversas como compras, lazer, alimentação, passeio e descanso; sendo tecnicamente apropriado quando existe comércio nos dois lados da rua gerando travessias frequentes de pedestres no meio de quadra e em múltiplas linhas de desejo. Quando bem situados, projetados e mantidos, os calçadões tendem a se tornar um local de destino e resultam em benefícios econômicos para o comércio adjacente (NACTO, 2018).

Na Europa, a Alemanha foi pioneira na implantação de calçadões comerciais em centros urbanos densos, com crescente circulação de automóveis. Esses espaços tornaram-se modelos para outras cidades da Europa e da América (RUBESTEIN, 1992). A Strøget, principal rua comercial do centro de Copenhague, eliminou os automóveis gradualmente, a partir de 1962, tornando-se, à época, um dos mais longos calçadões europeus. $\mathrm{Na}$ América do Norte, criaram-se ruas comerciais exclusivas para pedestres, como tentativa de atrair o público dos recentes shopping centers de subúrbio e reanimar o comércio dos Central Business Districts ('Centros de Negócios'). Orlas marítimas abandonadas também foram transformadas em áreas de compras festivas e animadas. Já os holandeses e alemães criaram, respectivamente, o Woonerf e o Wohnstraße: ruas residenciais adap- tadas para serem locais de lazer e recreação, enfatizando as relações de vizinhança (MEHTA, 2013).

A pedestrianização das ruas era, em geral, feita com a inserção de vegetação, piso diferenciado e mobiliário urbano, elementos que ajudavam a criar uma ambiência espacial similar a dos shoppings centers ou da Disneylândia. Visava-se revalorizar a "cultura da rua", qualificando o deslocamento a pé e incentivando uma maior animação dos espaços públicos (KOSTOF, 1992). Ao prover não só espaços de livre passagem, mas também lugares de permanência prolongada e encontro social, os calçadões favoreceram o turismo e o consumo em zonas históricas (FONSECA, 2012).

No Brasil, os calçadões começam a ser implantados no início dos anos 1970, década em que a população nacional passa a ser majoritariamente urbana e as primeiras regiões metropolitanas começam a ser institucionalizadas. É o momento da popularização do automóvel no país, difundido como símbolo de status social e apoiado pela expansão da infraestrutura viária. Nos centros antigos, as ruas estreitas - que não comportavam o maior volume de tráfego e nem possibilitavam alargamentos devido às edificações existentes - passam a apresentar congestionamentos de veículos. O pedestre, que já caminhava em passeios de largura reduzida, passou a entrar em conflito com o tráfego motorizado. A tomada de consciência a respeito dos impactos do uso massivo do automóvel sobre o meio ambiente e sobre a qualidade de vida urbana cria a oportunidade para as primeiras experiências de pedestrianização no Brasil, visando resolver esses conflitos (FONSECA, 2012). Outra motivação dos calçadões nos grandes centros urbanos foi "tentar revitalizar o comércio local que começava a sofrer o impacto da concorrência com o comércio dos bairros e dos recém-implantados shopping centers" (ROBBA; MACEDO, 2003, p. 136).

A implantação dos calçadões suscitou diferentes percepções na população em relação às mudanças que começavam a se materializar no espaço. Mencionou-se já a reação ocorrida em Curitiba, em 1972. Em 1974, foi também pedestrianizado um trecho da Rua da Praia, tradicional espaço comercial em Porto Alegre. Dis- 
cursos mais recentes de algumas porto-alegrenses indicam que a apreciação do calçadão como solução projetual não é uma unanimidade, mesmo transcorridas décadas de sua implantação, o que também instiga a realização deste artigo:

A construção do Calçadão, que aparentemente poderia facilitar tal prática [o footing ou 'passeio a pé'], é evocada por Décia [então com 88 anos] como uma "barbaridade", como um estrago da configuração da rua que antes permitia que os elegantes moços estacionassem seus carros e neles se escorassem para admirar o desfile das moças. Para Hilana [então com 63 anos], o "Calçadão" também foi objeto de repúdio; ela narra a desfiguração da sua tão bem quista Rua da Praia mediante a construção desta obra na década de 70 . "Revitalizar é uma coisa, não adianta buscar o que era que não vai vir nunca mais, né. Olha se tirar aquele calçadão já ganhou o prêmio. Eu acho que descaracteriza muito", confessa Hiliana. Para Tânia [então com 63 anos] o "Calçadão" não apenas descaracterizou a Rua da Praia, como também dificultou o acesso da população a este espaço e retirou a segurança das pessoas que ali caminhavam. (CUNEGATTO, 2009, p. 77).

\section{Metodologia}

A História Cultural, de maneira geral, parte do princípio de que o passado, resgatado através de registros e sinais, já chega ao historiador por meio de representações, isto é, formas discursivas e imagéticas utilizadas pelos indivíduos para expressarem a si próprios e o mundo que os cerca. Nessa linha de pesquisa, a História estabelece uma narrativa que representa o passado, investigando dados disponíveis sobre as experiências regressas (PESAVENTO, 2003). Trata-se, como bem coloca Chartier (2002, p. 7), de "colocar no centro de seu método as relações que mantêm os discursos e as práticas sociais". Essas representações se constituem como fontes para atingir versões compreensíveis, plausíveis, verossímeis do acontecido. A meta, como coloca Pesavento (2003, p. 51) é "chegar, o mais próximo possível, da verdade do acontecido. Mas no campo da História Cultural, o historiador sabe que a sua narrativa pode relatar o que ocorreu um dia, mas que esse mesmo fato pode ser objeto de múltiplas versões". Nesse sentido, o trabalho tenta resgatar essas múltiplas faces do passado, lembrando que não se admite a possibilidade de uma perspectiva de verdade única e que o "mais certo seria afirmar que a História estabelece regimes de verdade, e não certezas absolutas" (PESAVENTO, 2003, p. 51). Chartier (2002, p. 100) reforça que "abandonar essa intenção de verdade [...] seria deixar o campo livre a todas as falsificações [...]. Cabe aos historiadores, fazendo seu ofício, ser vigilantes".

Indícios do passado substituem o acontecido por representações do acontecido, as quais são visualizadas pelo historiador como fontes ou documentos de pesquisa, pois registram significados para as questões por ele levantadas. As ideias e imagens de representação coletiva formam um sistema dotado de relativa coerência e articulação, denominado imaginário. Em cada época, os indivíduos o constroem para conferir sentido ao real, de forma ampla, a partir de palavras, discursos, imagens, materialidades do espaço construído, práticas, ritos e performances. "O imaginário comporta crenças, mitos, ideologias, conceitos, valores, é construtor de identidades e exclusões, hierarquiza, divide, aponta semelhanças e diferenças no social. Ele é um saber-fazer que organiza o mundo, produzindo a coesão ou o conflito" (PESAVENTO, 2003, p. 43).

Nessa perspectiva, o que o historiador da cultura procura capturar no passado são, também, as sensibilidades, isto é, as componentes primárias de percepção e tradução da experiência mundana dos indivíduos. São elas que permitem o resgate de emoções, ideias, sentimentos, temores e desejos que não os do presente. Elas falam do real e do não real, do que se sabe e do que se desconhece, de intuições e mesmo do inventado. Ainda que se refiram a conceitos que não tenham existência real ou comprovada, sentimentos são reais e compõem a experiência do viver (PESAVENTO, 2003).

Para construir uma perspectiva possível de como a cidade de Santa Maria percebeu a implantação do calçadão, buscou-se 
analisar o discurso e as ações de um conjunto de atores sociais que puderam ser identificados: o arquiteto autor do projeto, os comerciantes, os moradores, os frequentadores e a Prefeitura. Devido ao calçadão ter sido implantado há mais de quarenta anos, as fontes de informação disponíveis foram: entrevista realizada com o autor do projeto (professor arquiteto Luiz Gonzaga Binato de Almeida) e reportagens publicadas no jornal local. A entrevista é considerada como fonte primária apenas quando se refere às sensibilidades do próprio arquiteto. Quando outros atores sociais são por ele mencionados, trata-se de fonte secundária, baseada na representação do próprio entrevistado sobre os fatos. O mesmo pode ser dito dos discursos extraídos da imprensa, nos quais se pressupõe que haja algum grau de subjetividade dos jornalistas. O recorte temporal da análise foca o ano de 1979, mas outras temporalidades são mencionadas com fins de contextualização.

\section{Objeto de Estudo}

A ocupação do sítio da atual cidade de Santa Maria (Figura 1), quinta maior população absoluta do Rio Grande do Sul (ADESM, 2019), iniciou-se em 1797 com a instalação de um acampamento militar provisório que abrigou a Comissão Demarcadora das terras de Portugal e Espanha nas colônias sul-americanas, o qual originou a primeira via da cidade, a Rua do Acampamento. Em 1801, a comissão retirou-se do local, deixando um pequeno núcleo de habitantes, elevado à categoria de cidade em 1876 (BE-

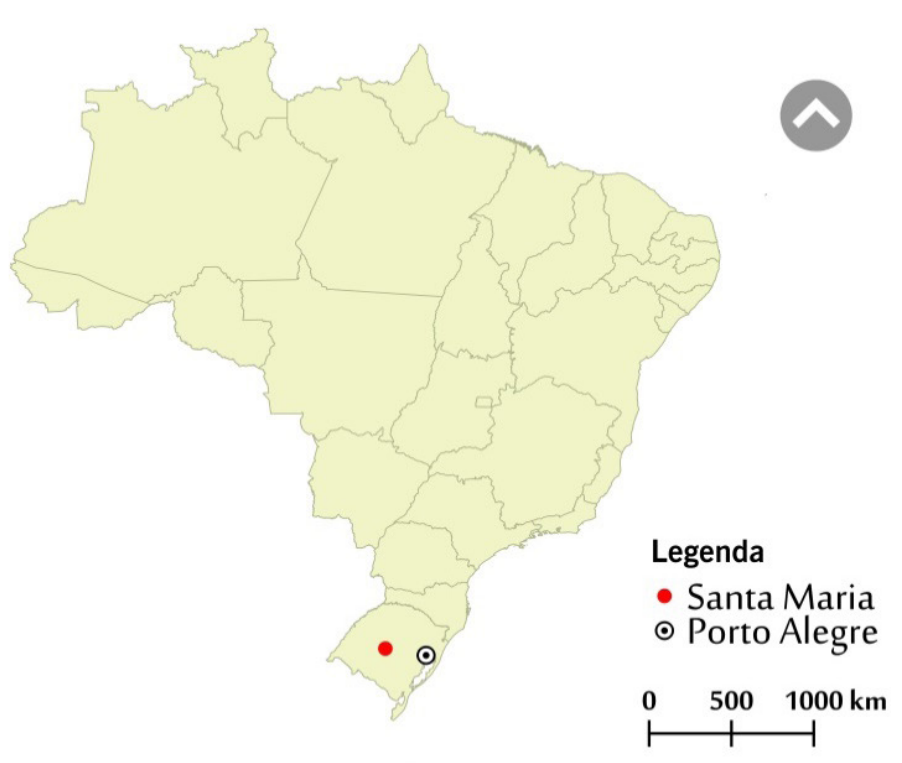

a

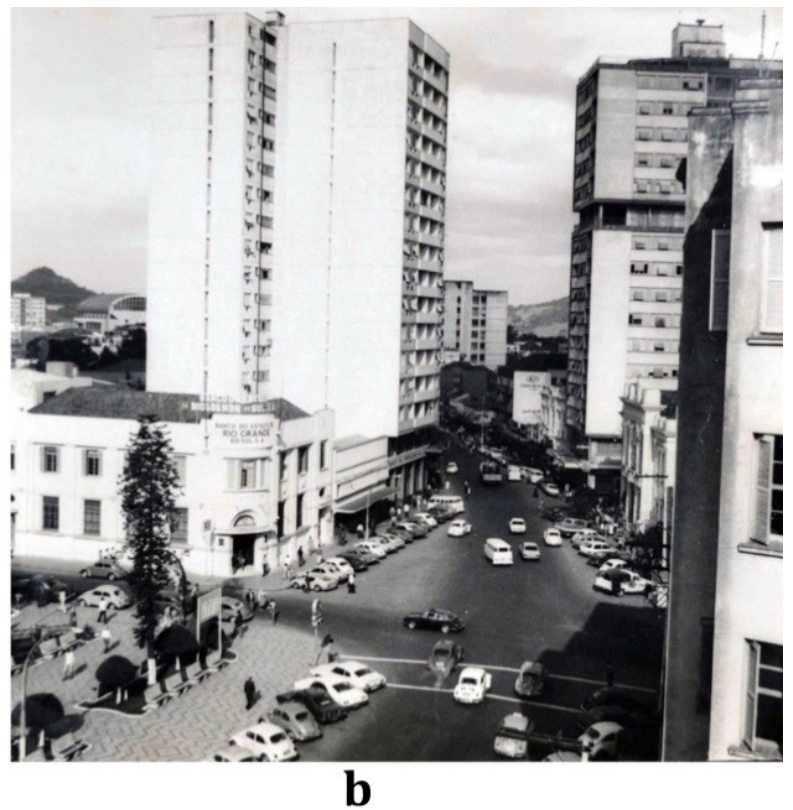

b

Figura 1 - Localização de Santa Maria, distante $290 \mathrm{~km}$ de Porto Alegre (a), cujo povoamento teve início no cruzamento da Rua do Acampamento (via vertical na foto) com a Rua Dr. Bozano (via horizontal na foto) (b). Hoje, o Viaduto Evandro Behr interliga a praça (à esquerda) com o calçadão, conforme a Figura 8.

Fonte: os autores (2019) (Figura 1a); AHMSM [197-] (Figura 1b). 
LÉM, 1989). Ainda no final do século XIX, a atividade comercial ali se consolidaria a partir da instalação da ferrovia que conectou Porto Alegre à fronteira oeste do estado e configurou Santa Maria como a centralidade das principais rotas do transporte gaúcho. $O$ entroncamento ferroviário trouxe inúmeras novidades que mudaram o aspecto da cidade, como iluminação, energia elétrica, correios, telefone e pavimentação de ruas, como a própria Av. Rio Branco, aberta como extensão para o norte do eixo da Rua do Acampamento até a Estação Ferroviária Central (BELTRÃO, 2013).

Nas imediações da Praça Saldanha Marinho (a principal do centro), a segunda via a ser aberta na cidade, a atual Rua Dr. Bozano, liga-se transversalmente à Rua do Acampamento (Figura 2).
Seu primeiro nome foi Rua Pacífica, alterado para Rua do Comércio em função da atividade predominante na sua primeira quadra. O logradouro só iria ganhar sua denominação atual em 1925, quando a municipalidade fez uma homenagem póstuma ao Dr. Bozano, advogado e jornalista da cidade (BELÉM, 1989; BELTRÃO, 2013). Mesmo com o novo nome, o antigo caráter permaneceu. Em termos de dinâmica social, a Primeira Quadra era - local onde a população gostava de fazer compras, passear e de paquerar no momento do tradicional footing (ALMEIDA, 2019; TV OVO, 2009).

O cinema de rua era outra atividade que intensificava o uso social local, existindo três grandes salas no centro da cidade, hoje desativadas. Antes de a televisão se difundir no Brasil, os três

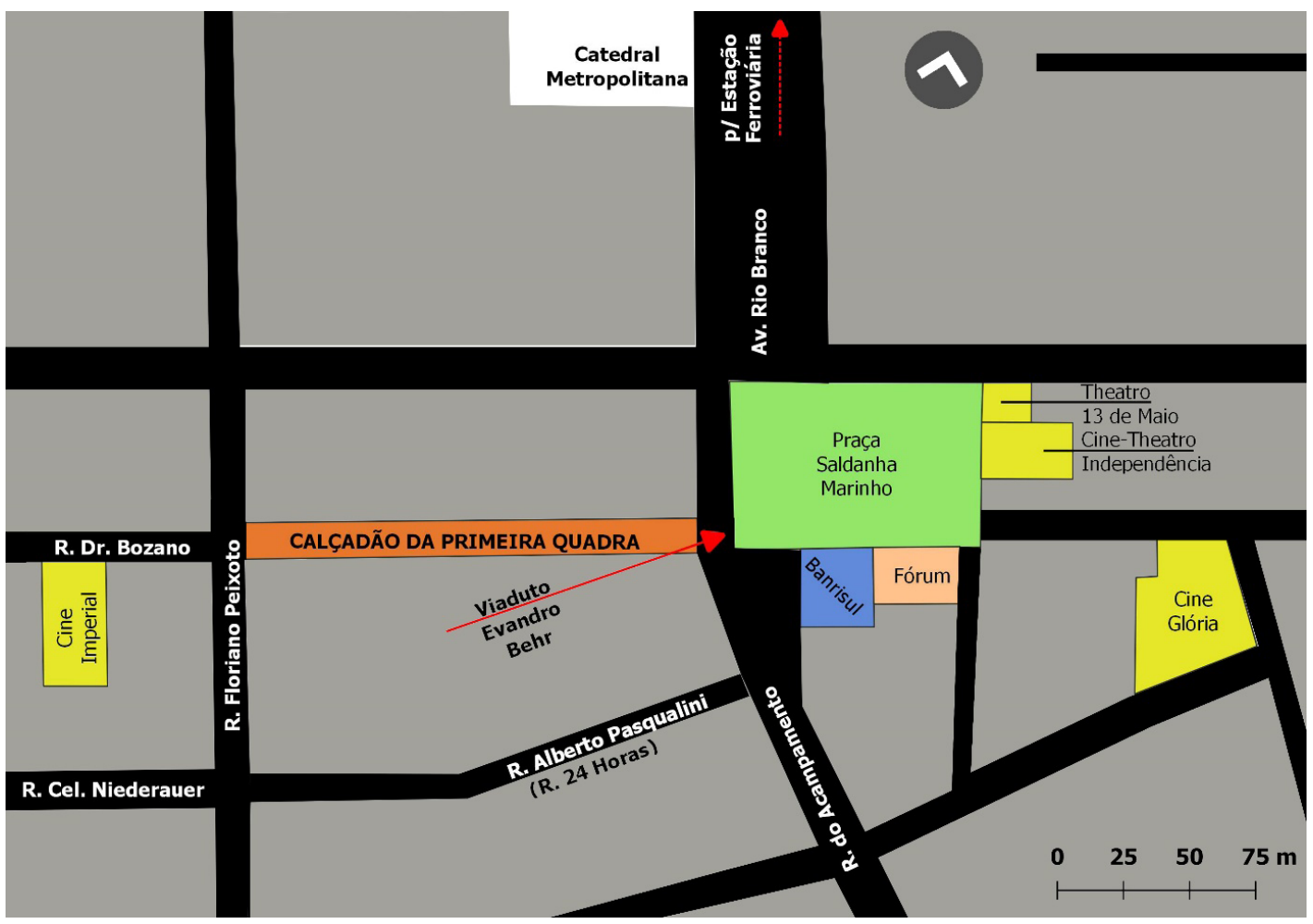

Figura 2 - Mapa esquemático do Centro de Santa Maria.

Fonte: os autores (2019). 
cinemas funcionavam simultaneamente, oferecendo entretenimento ao público. À noite, quando terminavam as sessões, o ponto do encontro social era a Primeira Quadra, que oferecia restaurantes, cafés, confeitarias, sorveterias e vitrines de casas comerciais (ALMEIDA, 2019). A grande circulação diurna e noturna de pedestres pelo centro indicava sua vitalidade e segurança, possivelmente maior do que nos dias de hoje. Assim, na segunda metade do século $X X$, as funções sociais e comerciais da Primeira Quadra (Figura 3) já estavam consolidadas no imaginário dos santa-marienses.

Em seu primeiro mandato, de 1977 a 1982, o prefeito Osvaldo Nascimento da Silva - eleito pelo Movimento Democrático Brasi- leiro (MDB), partido de oposição ao governo militar - viabilizou uma série de melhorias urbanas por meio de convênios celebrados entre a Prefeitura Municipal e a Empresa Brasileira de Transportes Urbanos (EBTU), inseridos no Programa de Cidades de Porte Médio. Esse programa fazia parte de uma política de fixação da população em cidades do interior, visando diminuir as migrações para as metrópoles. Nesse sentido, obras seriam financiadas com recursos da EBTU sem necessidade de retorno por parte do município, ou seja, a fundo perdido (PEDESTRES, 1979). Dentro do elenco de obras municipais, constava a pavimentação de ruas, a criação e/ou remodelação de praças e a pedestrianização da Primeira Quadra (ALMEIDA, 2019).

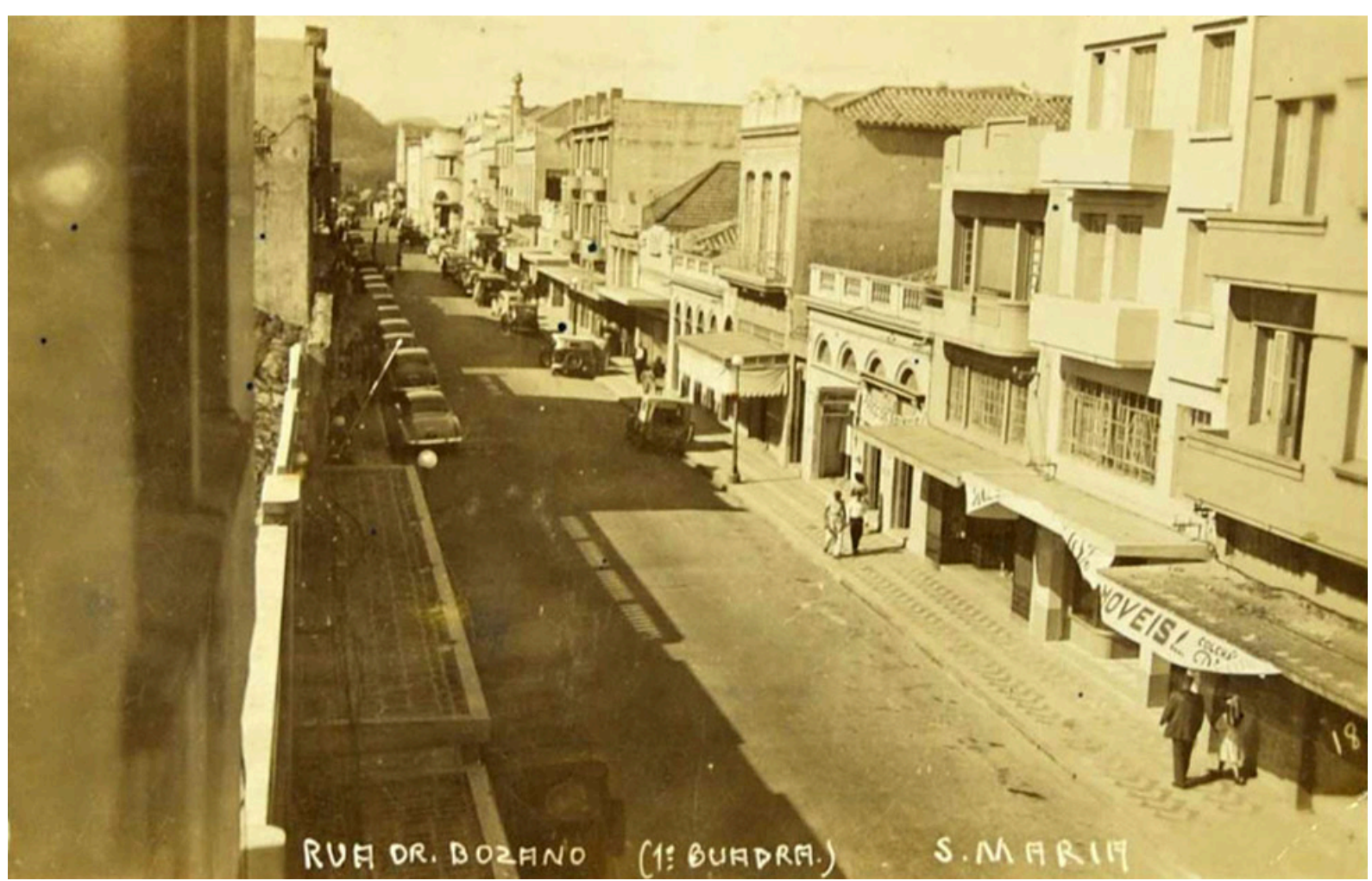

Figura 3 - A Primeira Quadra antes da pedestrianização, com destaque para o comércio.

Fonte: AHMSM [entre 1920 e 1960]. 
Em 1977, não havia arquitetos trabalhando na Prefeitura Municipal de Santa Maria. Na gestão de Nascimento, a função de Secretário de Planejamento foi exercida por Carlos Alberto Robinson, anteriormente vereador, formado em Direito pela Universidade Federal de Santa Maria (UFSM) e, futuramente, docente dessa instituição. Segundo Almeida (2019), Robinson teria feito disciplinas no extinto Curso de Urbanismo da Universidade Federal do Rio Grande do Sul (UFRGS), precursor do atual Programa de PósGraduação em Planejamento Urbano e Regional (PROPUR). Além de uma visão progressista e multidisciplinar do urbanismo, Robinson possuía contatos políticos que o auxiliariam com informações em relação aos convênios. Nascimento, também formado em Direito pela UFSM e favorável à visão dos técnicos, foi convencido por Robinson a requisitar arquitetos e engenheiros para colaborar junto à Prefeitura. Na época, as atividades de construção civil em Santa Maria ainda eram exercidas predominantemente por engenheiros. Dos poucos arquitetos ali residentes, destacavam-se Pepe Reyes e José Antônio Brenner (ALMEIDA, 2019).

Em parte, essa escassez de arquitetos na cidade decorria do fato de que a implantação do ensino de Arquitetura no Rio Grande do Sul deu-se somente em 1945. Antes disso, a profissão era realizada por arquitetos de outras regiões. Em 1952, com a federalização da atual UFRGS, os dois cursos que funcionavam de forma independente foram fundidos na criação da Faculdade de Arquitetura da UFRGS, a qual foi a única escola a formar arquitetos no estado por quase vinte anos. Em 1971 foi implantada uma segunda escola, na Universidade do Rio dos Sinos - UNISINOS, em São Leopoldo, cidade da Região Metropolitana de Porto Alegre (RMPA). Ao longo dos anos 1970, outras escolas surgiriam: em Canoas (também na RMPA), na Universidade Luterana do Brasil ULBRA; em Porto Alegre, no Centro Universitário Ritter dos Reis UNIRITTER e, em Pelotas (sul do estado), na Universidade Federal de Pelotas - UFPEL. Somente na década de 1990 que foi criada uma escola de Arquitetura na Universidade Federal de Santa Maria (SALVATORI, 2008).

Nesse contexto, em que engenheiros locais elaboravam projetos de edificações, eram ofertadas disciplinas de Arquitetura e de
Urbanismo no curso de Engenharia Civil da UFSM, ministradas por professores visitantes arquitetos. Um desses professores foi José Albano Volkmer, futuramente presidente do Instituto de Arquitetos do Brasil e do Conselho Regional de Engenharia e Arquitetura, que lecionava na UFSM aos sábados e, durante a semana, no Curso de Arquitetura e Urbanismo da UNISINOS, em São Leopoldo. Em 1976, Volkmer convidou seu colega de trabalho na UNISINOS, o professor arquiteto Luiz Gonzaga Binato de Almeida (Figura 4), para vir lecionar Urbanismo também em Santa Maria.

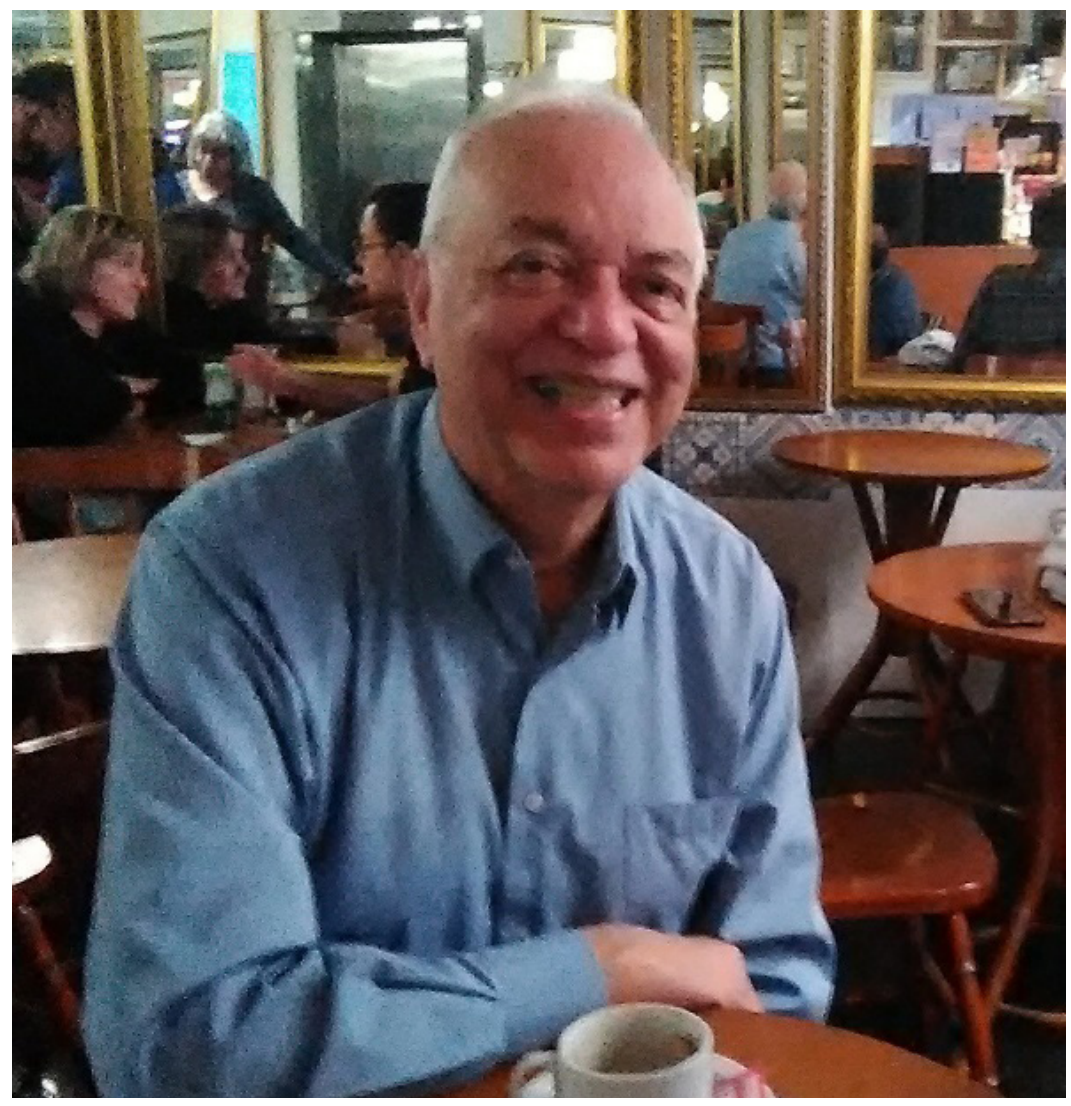

Figura 4 - Prof. Luiz Gonzaga Binato de Almeida. Fonte: os autores (2019). 
O Prof. Binato, como é conhecido, nasceu em Carazinho (RS) e formou-se pela UFRGS em 1972. Na época, ele achou a proposta interessante, visto que possuía parentes na cidade e que a UFSM abriria perspectivas profissionais futuras. No final de 1977, foi oferecida a Binato a possibilidade de trabalhar em tempo integral na UFSM (ALMEIDA, 2019).

Por indicação de Robinson, Binato foi convidado pelo prefeito a trabalhar como Assessor de Planejamento do Gabinete do Prefeito, um cargo de confiança. Logo, Binato foi incumbido de projetar o calçadão e conseguiu duas arquitetas para auxiliá-lo: Valéria Ferraro Athayde, formada pela UNISINOS em 1977, que trabalhou alguns meses no projeto e Silvia Inez Zembruski Nunes, formada pela UFPel em 1978, que acompanhou o final do projeto. Além do calçadão, Binato supervisionou localmente os trabalhos de elaboração do segundo Plano Diretor da cidade, aprovado em 1979. Esse plano foi elaborado pela empresa Proplasa, de São Paulo, cuja equipe contava com técnicos de renome internacional, como Roberto Burle Marx, que esteve em Santa Maria para averiguar os recursos paisagísticos da cidade e propor estratégias para suas áreas verdes (ALMEIDA, 1979).

No início de 1978, a Primeira Quadra foi fechada ao trânsito, passando já a ser local de reunião social (O CALÇADÃO, 1979). Concluído o projeto no mesmo ano e vencida a concorrência de execução pela Construtora Portella, a obra iniciou-se em 02 de janeiro de 1979, ao custo total de Cr\$2.386.000,00 (CALÇADÃO, 1979b), quantia equivalente hoje a $R \$ 594.246,57$, corrigida a inflação (BANCO CENTRAL DO BRASIL, 2021). Marcando o início da semana comemorativa do aniversário da cidade, após um correcorre diurno e noturno com as obras, no dia 10 de maio de 1979 , às 18 horas e 30 minutos, o prefeito inaugurou o calçadão da Primeira Quadra, em solenidade que contou com apresentações artístico-culturais (Figura 5) (PREFEITO, 1979a). Binato recorda que foi um evento grandioso: muita gente fez-se presente para ver a novidade, pois fazia muito tempo desde a última inauguração de uma obra no centro da cidade. Além dos santa-marienses, o espaço atraía pessoas de outras cidades próximas, que vinham visitá-lo (ALMEIDA, 2019).

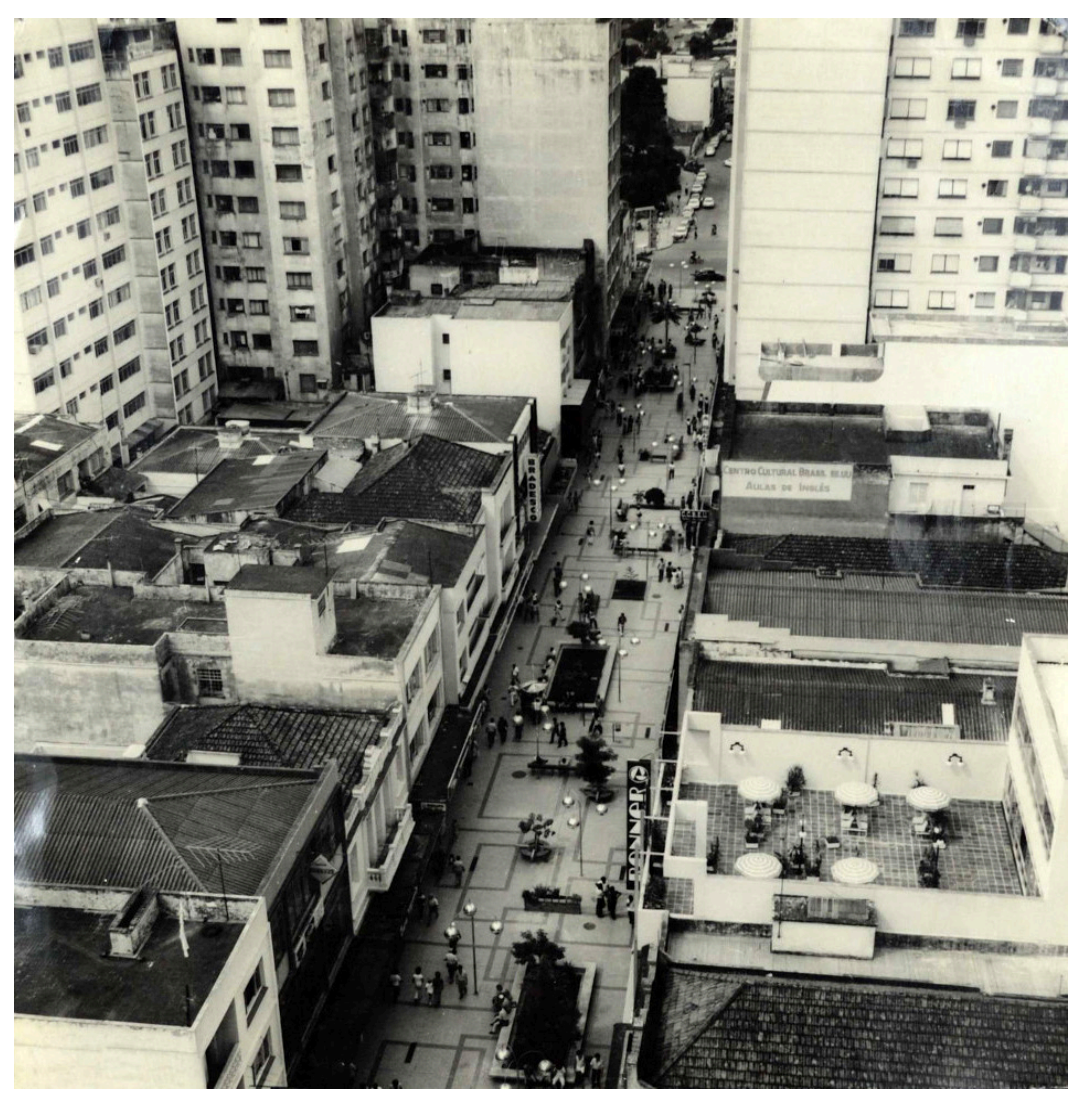

Figura 5 - O calçadão após a finalização da obra. Fonte: AHMSM [entre 1979 e 1989b).

\section{Atores Socials e Suas Narrativas}

\section{O ARQUITETO}

Segundo Binato, "o calçadão foi a primeira obra que revolucionou a nossa cidade", visto que houve muita reação a ela antes mesmo de o projeto ser finalizado. Quando começou a se falar em pedestrianizar a Rua Dr. Bozano, defensores do seu caráter tradicional acharam que o encontro social e a animação iriam 
acabar na Primeira Quadra. O arquiteto argumentava que, na verdade, o calçadão iria consagrar esse encontro: no momento em que a rua fosse fechada ao trânsito de veículos e se fizesse uma calçada contínua, o leito seria muito mais animador. O calçadão de Curitiba, de autoria do arquiteto Abrão Assad e desenvolvido na primeira gestão do prefeito (também arquiteto) Jaime Lerner, foi a grande obra de referência. Binato foi até lá para conhecê-lo, avaliá-lo, sendo acompanhado pela equipe do Instituto de Pesquisa e Planejamento Urbano de Curitiba (IPPUC), onde havia feito estágio anteriormente (ALMEIDA, 2019).

Em Santa Maria, inicialmente fez-se um levantamento dos estabelecimentos comerciais existentes na Primeira Quadra, sendo necessário um trabalho de sensibilização junto aos proprietários, para explicar que a obra demoraria e atrapalharia aquela parte tão vital da cidade. Quanto à paisagem, a intenção do arquiteto era que houvesse vegetação e mobiliário, para tornar a rua agradável, animada, propícia ao lazer e ao encontro (Figura 6). Foram projetados três diferentes tipos de banco, um sóciopetalado, que tende a unir os usuários com seu arranjo configurando um ambiente de estar, propiciando o contato visual; e dois sociofugidios, que dispõem os usuários de maneira menos flexível, de modo que se possa sentar ao lado de outros, mas sem interações visuais face-a-face. Os bancos sóciopetalados foram concebidos com um desenho tradicional com ripas de madeira e estrutura metálica, semelhantes aos existentes à época na Praça Saldanha Marinho. O primeiro tipo sociofugidio era um banco circular com assento em madeira e estrutura em concreto, em cujo centro era plantada uma árvore para proporcionar sombreamento. O segundo tipo era um banco contínuo em concreto, disposto nas bordas das grandes floreiras retangulares em alvenaria (ALMEIDA, 2019)

Segundo o projeto, as muretas de tijolo à vista serviriam para apoiar caixas de flores pré-moldadas em amianto, que poderiam ser trocadas, alternando-se as espécies para uma diversidade de cores. Os telefones públicos foram previstos em estruturas que comportavam três unidades, com cobertura circular em acrílico protegendo aparelhos e usuários das intempéries. A luz viria de

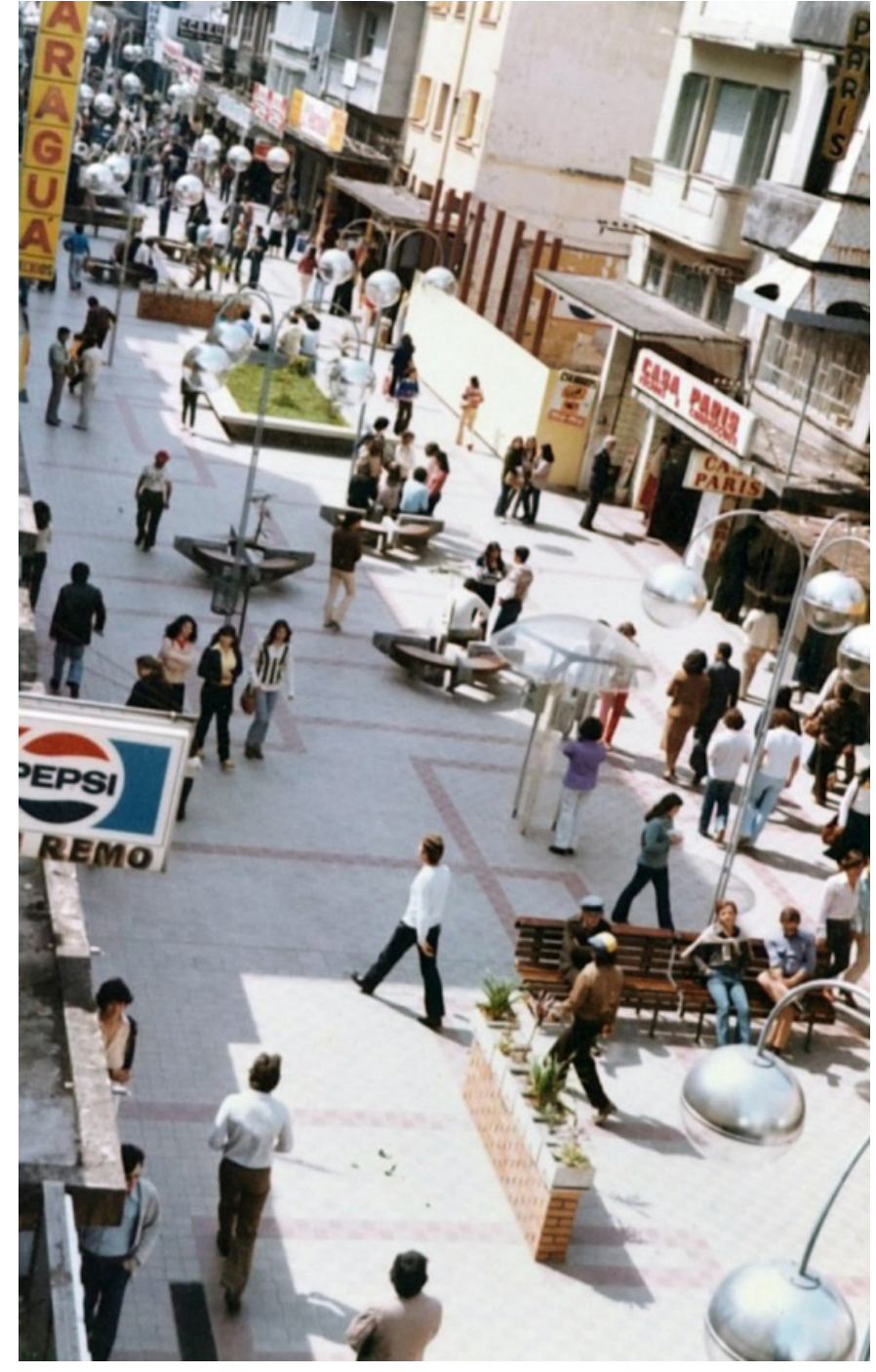

Figura 6 - Vista aérea do calçadão da Primeira Quadra, mostrando o desenho do piso, tratado como painel; o mobiliário, com destaque para os bancos sóciopetalados em madeira, bancos sociofugidios em concreto, muretas de apoio para floreiras, luminárias e abrigos de telefone em acrílico.

Fonte: AHMSM [entre 1979 e 1989]. 
conjuntos de três luminárias em forma de globo, acopladas em postes metálicos. O Corpo de Bombeiros, ao apreciar o projeto, julgou que as luminárias poderiam trazer alguma dificuldade de ação no combate a incêndios, sendo liberadas após o comprometimento da instalação de hidrômetros junto às floreiras. Lixeiras pré-fabricadas completavam o projeto de mobiliário. Finalmente, o piso foi elaborado utilizando ladrilhos hidráulicos nas cores cinza e rosa, formando retângulos que se entremeavam. Como já havia edifícios altos no entorno do calçadão, a intenção era de que quem o avistasse de cima percebesse um desenho geométrico explícito, como se fosse um painel (Figura 7) (ALMEIDA, 2019).

$\mathrm{O}$ arquiteto recorda do projeto com certo orgulho, pois esse ajudaria a estabelecer uma imagem muito diferente para a cidade, visto que nem a Primeira Quadra e nem a cidade possuíam atrativos em termos de urbanismo e/ou paisagismo há um considerável tempo. Binato mencionou com bom humor uma charge publicada em um jornal local que retratava os usuários do calçadão com óculos Ray-Ban, tamanho o ofuscamento causado pelo excesso de iluminação. "Acho até que foi um elogio, afinal, a luz era segu- rança", disse o arquiteto. Em sua opinião, havia poucas pessoas contrárias à obra: a maioria desejava novidades para a cidade (ALMEIDA, 2019).

Um lamento do projetista diz respeito às suas expectativas de animação permanente do local: não se efetivaram as mesas na calçada em frente aos bares e cafés; e as poucas vezes em que houve música ao vivo ou artistas se apresentando aconteceram, geralmente, no período de Natal. Na opinião de Binato, até hoje os comerciantes não aproveitam essa oportunidade de uso do espaço público, justificando que a chuva e o vento atrapalham a freguesia. Disse ele: "Bem que eu gostaria disso, mas não há essa tradição aqui. Tem os capoeiristas, de vez em quando. Um que outro palhaço, fazendo propaganda do seu trabalho" (ALMEIDA, 2019). Um sonho, não realizado em 1979, era interligar fisicamente o calçadão e a praça (ALMEIDA, 2019), intervenção que só se concretizaria na administração do prefeito Evandro Behr (1989-1992), engenheiro e ex-diretor-geral do Departamento Autônomo de Estradas de Rodagem (DAER), eleito pelo antigo Partido Democrático Social (PDS), sucessor da ARENA. Para isso, foi

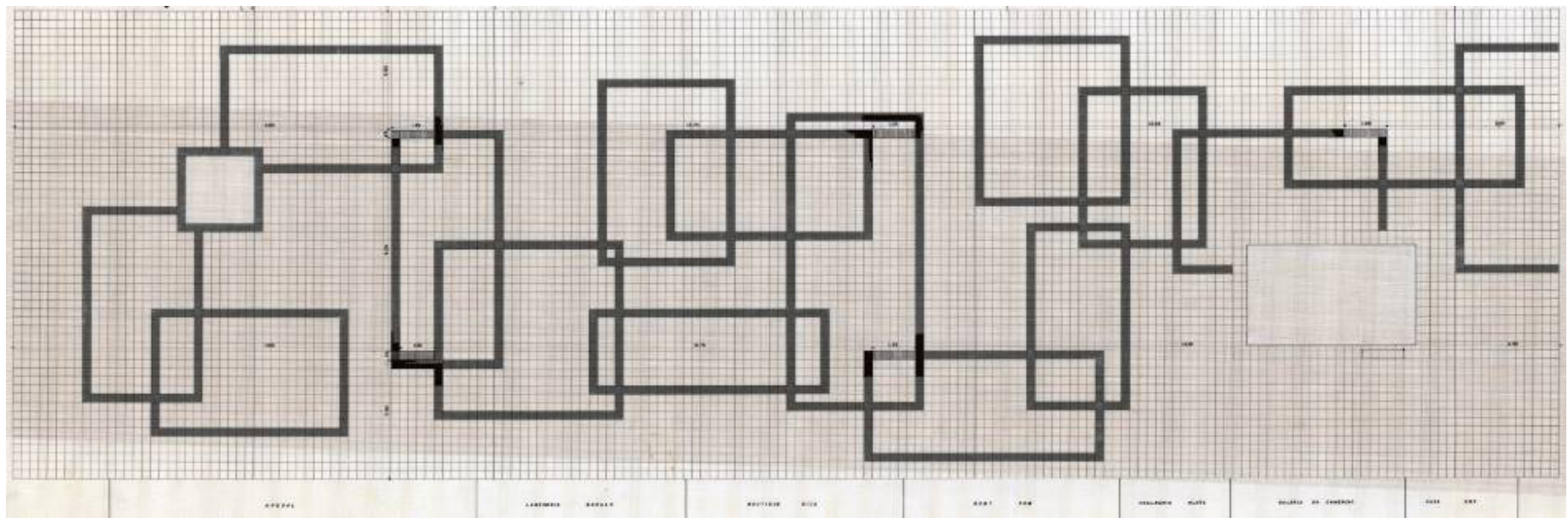

Figura 7 - Diagrama de pavimentação do Calçadão. Fonte: adaptado de Almeida e Athayde (1978). 
construído um viaduto batizado com o nome do prefeito, sob o qual se conectou de norte a sul o eixo viário Av. Rio Branco, Rua do Acampamento e Av. Fernando Ferrari; e, sobre ele, de leste a oeste, os dois principais espaços de lazer da cidade (Figura 8).

\section{Os COMERCIANTES}

Em 1979, o comércio existente na Primeira Quadra era um pouco diferente do atual: a maioria dos proprietários era santa-mariense e as lojas ofereciam marcas de qualidade tradicionais. Binato relatou que sofreu críticas negativas de alguns comerciantes, sob a forma de palpites e desconfianças em relação à execução ainda não finalizada: "estamos vendo que estão colocando umas greIhas para o esgoto pluvial. Provavelmente as mulheres vão quebrar o salto alto quando passarem por elas". Mas havia também fortes aliados entre os comerciantes, como Salvador Isaia, das Casas Eny, que foi tão favorável à obra, a ponto de ser homenageado postumamente com a alteração da denominação da via para Calçadão Salvador Isaia (ALMEIDA, 2019). Os jornais da época registraram a opinião de alguns lojistas, em geral favoráveis à obra, mas com receio do aparecimento de "marginais", "pivetes" e "elementos inconvenientes entre a freguesia", atraídos pela

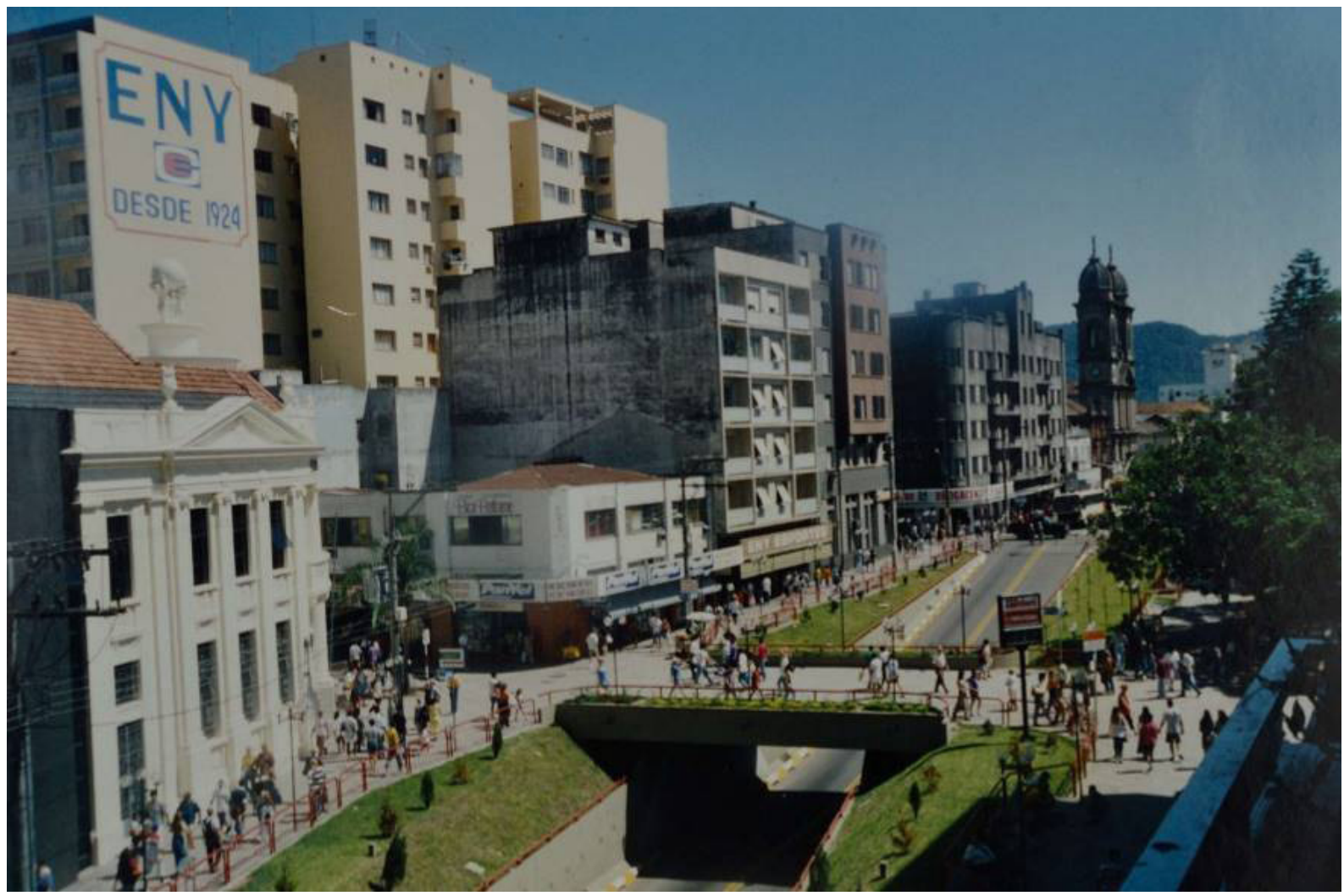

Figura 8 - Passagem de pedestres entre o calçadão (à esquerda) e a Praça Saldanha Marinho (à direita) pelo Viaduto Evandro Behr. A Rua do Acampamento foi rebaixada para passagem dos veículos e as suas calçadas junto aos taludes gramados foram alargadas. A visual antiga do lado oposto do cruzamento é retratada na Figura $1 \mathrm{~b}$.

Fonte: AHMSM [entre 1991 e 2000]. 
aglomeração de consumidores, semelhante ao que estava sendo divulgado sobre outros calçadões brasileiros (CALÇADÃO, 1979b).

Renato Rios, da Bobby Som Discos e Fitas, alertou para a necessidade de o calçadão ter uma infraestrutura eficiente e um local fixo nas suas redondezas para o estacionamento de caminhões, permitindo a carga e a descarga. Waldemar Cavalheiro, procurador da Livraria do Globo, disse ser favorável, acreditando que o calçadão traria benefícios, pois seria um trabalho belo, que enfeitaria a cidade e chamaria a atenção do pedestre. Pedro Saccol, da Central de Máquinas, afirmou que o calçadão valorizaria o centro, principalmente se bem iluminado e policiado. Também acreditava que o principal beneficiado seria o pedestre, que teria sua tarefa de consumidor bastante facilitada, sem se preocupar com automóveis. Iran Villa Porto, gerente das Casas Pernambucanas, considerou o calçadão uma "boa", exceto pelos distúrbios das obras. Elba Soccal, da Lancheria Badalo, acreditava que haveria melhoria (CALÇADÃO, 1979b)

Para o vendedor de jornais Manuel Saldanha, que mantinha sua banca há quinze anos na Primeira Quadra, o calçadão era sinônimo de incertezas, pois não sabia se poderia permanecer no local após o fim das obras, mesmo após o prefeito ter prometido que não o tiraria dali. Esperançoso, explicou em entrevista que já pensava em adquirir uma nova banca, mais bonita, pois a atual não combinaria com o calçadão. Também dizia: "o movimento da primeira quadra 'vai mudar para melhor' e que o tipo de gente vai ser 'da elite e do comércio. A polícia não permitirá gentinha'" (PARA, 1979).

\section{OS MORADORES}

No final da primeira semana de obras, a manchete do jornal de sábado anunciou a opinião em uníssono dos residentes da Primeira Quadra: "CALÇADÃO: estacionamento é a maior queixa dos moradores" (CALÇADÃO, 1979a). Impossibilitados de estacionar perto de seus apartamentos, eles reclamavam das dificuldades de carregar bagagens, principalmente em dias de chuva. A senhora Magoga relatou não ser muito a favor do calçadão e que já havia entrado em um grave atrito com soldados da Brigada Militar responsáveis pela ordem no trânsito. Entretanto, ela reconheceu que, apesar de todos os senões, a obra embelezaria o centro e seria uma maravilha para passear. Por motivos semelhantes, Zilá Hamilton se mostrou contra a implantação do calçadão, mesmo com a beleza que proporcionaria ao centro. Maria Tereza Silveira, moradora da cidade de Faxinal do Soturno, mas visitante frequente de seus parentes residentes na Primeira Quadra, afirmava que antes das obras era muito mais prático acessar o edifício. Em função da "regalia" da carga e descarga concedida exclusivamente aos comerciantes, Celi Teixeira considerou "nada boa a implantação do calçadão", principalmente devido ao problema de coração do marido, que seria obrigado a caminhar por um trecho mais longo. Conforme Celi, os moradores estariam organizando uma comissão para pedir ao prefeito que providenciasse uma solução para os seus problemas (CALÇADÃO, 1979a).

\section{OS USUÁRIOS DO ESPAÇO}

Luiz Mário Camilo, advogado, afirmou que os principais beneficiados seriam os comerciantes e os consumidores, que ficariam protegidos do tráfego de veículos. Julgou que o impedimento de trafegar naquele quarteirão não se mostrava problemático e que o local já era caracterizado pelo encontro de colegas de sua classe. Brincou que, agora, a calçada ficaria mais ampla para "contemplar os atrativos femininos" (CALÇADÃO, 1979a). Para José Heron Rossetto, capitão do Corpo de Bombeiros, o calçadão iria humanizar muito a cidade, sendo necessário oferecer mais espaço para as pessoas circularem, fora do burburinho do centro. Lamentou que "os grandes centros tendem a se tornar áreas exclusivas para o comércio", fazendo com que os moradores procurem "locais pelas margens da cidade, principalmente nos bairros, para morar" (CALÇADÃO, 1979a). Humberto Gabbi Zanatta, poeta, escritor, advogado, jornalista, sociólogo, professor e ex-vereador local, publicou na época da inauguração: "inicialmente criticado por alguns com aspereza, por outros, com benevolência, aceito desde o início pela maioria, o calçadão, ao natural vai se firmar como uma opção tremendamente válida no 
contexto humano-urbanístico de nossa Santa Maria" (Figura 9) (ZANATTA, 1979).

Já Sérgio Blates, advogado e vereador, disse ser favorável ao calçadão, porém acreditava que essa não era uma obra de maior prioridade, já que a Praça Saldanha Marinho e a Primeira Quadra poderiam servir perfeitamente para o lazer se continuassem apenas interditadas ao trânsito de automóveis como ocorrera em outros anos. Para ele, o custo do calçadão seria suficiente para dar uma melhor estrutura a muitas vilas marginalizadas e às estradas precárias do interior do município que escoavam a produção agrícola (CALÇADÃO, 1979a). O cronista José Gomes Barreto caracterizou com certa ironia o calçadão como um "pequeno asilo cercado de veículos", em que o pedestre devaneia despreocupado "entre floreiras e orelhões [...], num estilo que sugere uma das melhores invenções recentemente voltadas ao passado" (BARRETO, 1979).

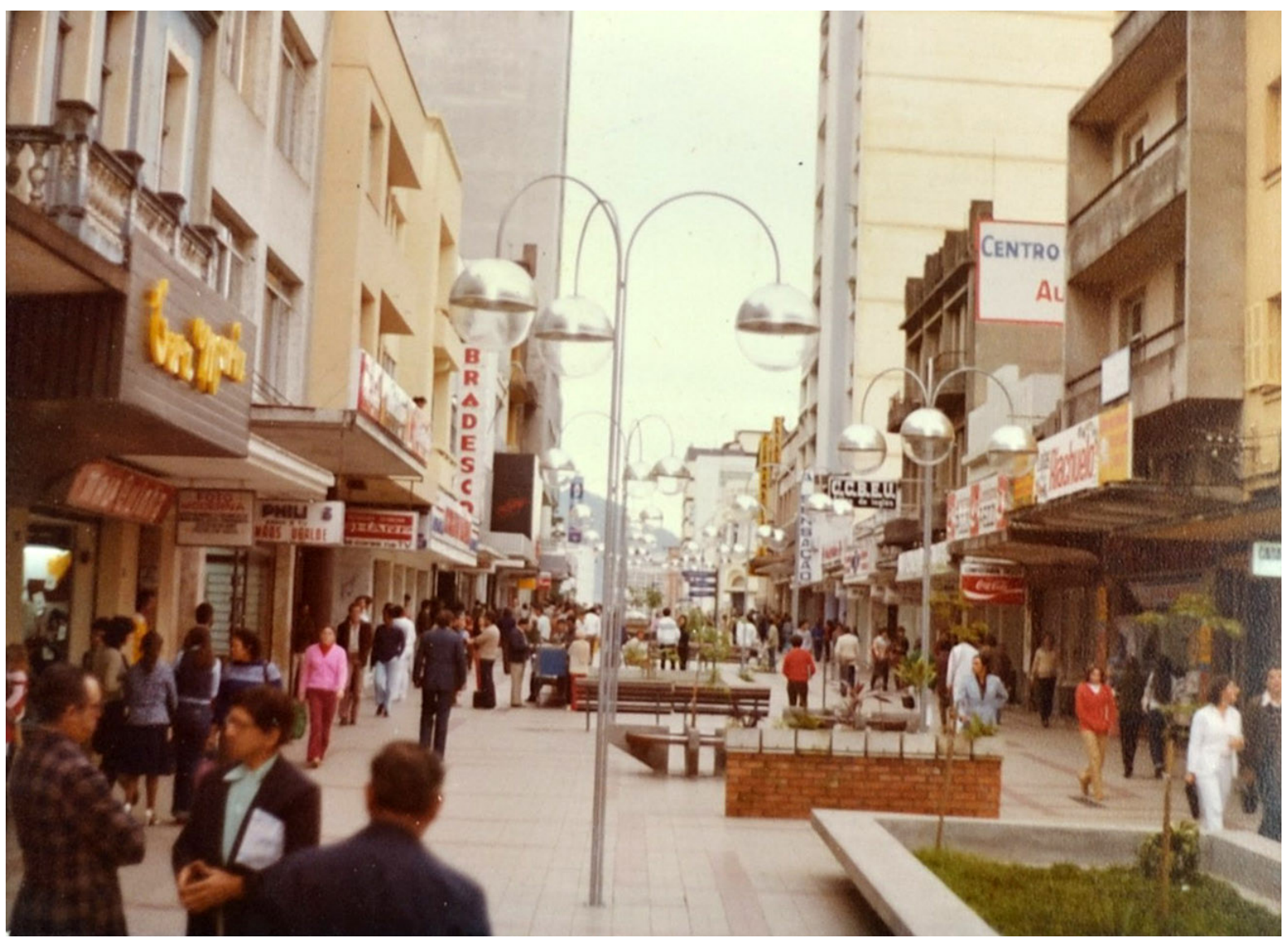

Figura 9 - O calçadão como espaço social.

Fonte: AHMSM [entre 1980 e 2000] 


\section{A Prefeitura}

Uma preocupação da Administração Municipal foi evitar que os vendedores ambulantes dominassem o espaço do calçadão. Binato explica: "não éramos contra o camelô, mas o calçadão não era o espaço previsto para essa atividade". E assim foi aprovado um regulamento especial estabelecendo normas para o uso público do calçadão, uma espécie de código de posturas publicado por meio de decreto municipal. A respeito desse controle, Binato brincou que o espaço chegou a dispor de um guarda da prefeitura: "E quando eu passava, aí é que ele fazia mais ainda uma encenação, porque ele sabia que era eu quem tinha criado o calçadão. Ele fazia uma encenação absoluta e absurda: 'Saia daqui, que tá chegando o homem responsável pelo projeto!'" (ALMEIDA, 2019).

De acordo com o decreto do Executivo, não seria permitido: atividades comerciais sem condições legais para a sua instalação ou não satisfazendo as exigências estabelecidas pelo Município; atividades de engraxates; fixações de cartazes de propaganda ou outras espécies de publicidade; venda de entradas, carnês e objetos de artesanatos; concentrações estudantis políticas ou outras de qualquer natureza; o uso de patins, skate, motocicletas e veículos de qualquer natureza, exceto ambulâncias, carro dos bombeiros e transporte de valores; lavagem de prédios antes das $20 \mathrm{~h}$ e ocupação do espaço público com mesas e cadeiras por lancherias, bares, cafés e restaurantes além de sua correspondente testada ou fora do período entre $18 \mathrm{~h}$ e $24 \mathrm{~h}$. Outras restrições faziam-se em relação a horários para mudanças, carga e descarga, recolhimento de lixo, além de orientações para marquises em novas construções e fixação de placas nas edificações (CALÇADÃO, 1979c).

\section{Considerações Finais}

As fontes consultadas possibilitaram a construção de uma perspectiva abrangente a respeito das diferentes narrativas sobre o calçadão e o estabelecimento de um registro histórico que contextualiza a implantação do projeto. Mesmo sendo utilizadas fontes secundárias para analisar o discurso de alguns atores so- ciais, a sua interpretação é validada pela metodologia se consideradas como verdades plausíveis e não absolutas. Nesse sentido, foi possível responder à questão de pesquisa: como esses projetos pioneiros de pedestrianização foram percebidos nas cidades do interior do Brasil? Identificou-se que os moradores da Primeira Quadra foram os que se mostraram mais contrários à obra. Já a Prefeitura, o arquiteto responsável pelo projeto, os comerciantes e os usuários do espaço que foram entrevistados apresentaram discursos alinhados a um objetivo comum: construir a imagem de um centro mais humano e moderno, tal como cidades maiores estavam fazendo.

O autor do projeto pretendeu através do calçadão consagrar um genius loci identificado na Primeira Quadra: o espaço central do encontro social santa-mariense. Para isso, os automóveis deveriam ser substituídos por vegetação e mobiliário, tornando o espaço muito mais agradável para os pedestres. Seu discurso enfatizou as preocupações funcionais, estéticas e de contexto do projeto, havendo uma clareza de visão quanto aos impactos positivos da pedestrianização do centro.

Como a maioria dos lojistas da Primeira Quadra à época era santa-mariense, identificaram-se discursos marcados pela ausência de indiferença. Houve tanto um desejo de valorização do seu espaço por meio de melhorias estéticas e funcionais, bem como certo receio do que viria com elas, como os famigerados 'elementos inconvenientes', claramente uma preocupação com a seleção dos usuários do espaço. Isso remete ao sentimento do vendedor de jornais, cuja permanência no local após a obra, ainda não garantida, aproximou-se do problema da gentrificação. Caso não houvesse o esclarecimento e o apoio declarado de muitos comerciantes, talvez tivesse ressoado com maior força na Prefeitura as vozes dos moradores, desejosos de poder estacionar em frente aos seus edifícios. Para quem residia na Primeira Quadra, prevaleciam, naturalmente, interesses particulares e a praticidade cotidiana em detrimento daqueles da coletividade, apesar dos reconhecidos benefícios estéticos.

Os usuários do espaço que foram entrevistados na época, expressaram satisfação com as oportunidades de lazer que seriam ofe- 
recidas no calçadão, o que demonstra certa aceitação da obra pelo público geral. Algumas ressalvas foram identificadas pelo relato de alguns cidadãos mais nostálgicos mencionados por $\mathrm{Bi}$ nato, que temiam o fim do encontro na Primeira Quadra, possivelmente orientados pelo imaginário de um passado ainda recente. Houve também quem ironizou o propósito do projeto, considerando o footing ultrapassado. Esse discurso não necessariamente significou um posicionamento contrário à obra, tal como o do vereador que não considerava o embelezamento como prioridade de investimentos na cidade. Certamente poderiam ser encontrados outros críticos do calçadão à época, porém os jornais consultados não publicaram seus discursos, ficando essa possibilidade como especulação.

A municipalidade - na qual se inclui o prefeito e o secretário de planejamento - mostrou-se sensível às tendências urbanísticas curitibanas, ficando interessada em associar a sua imagem às obras de humanização e melhoramento. Essas conotam uma visão progressista e um desejo de modernização da cidade. Mesmo que essas obras não tenham se restringido ao calçadão, ele as capitaneou, funcionando como uma metonímia urbana: a parte substituiu o todo na representação simbólica da cidade. A 'cereja do bolo' do Centro, inaugurada no aniversário da cidade, recebeu um código de posturas próprio e policiamento para garantir a ordem, considerando a importância readquirida pelo local.

Este estudo permite concluir que, considerando as diferentes percepções e interesses em jogo, a pedestrianização do centro de Santa Maria tornou-se possível a partir do alinhamento de fatores de contexto e de entendimentos como: a existência de um programa nacional de valorização de cidades médias; um prefeito aberto ao parecer dos técnicos; um secretário com visão progressista e bons contatos políticos; e, por fim, uma massa crítica representada pelo arquiteto, que elaborou um projeto apoiado pela maioria dos comerciantes locais. Pode-se dizer que, à época, as decisões de transformação dos espaços públicos tendiam a ser mais centralizadas, envolvendo um menor grupo de pessoas. Hoje, a informação e a expressão de ideias estão acessíveis a cada vez mais pessoas. Portanto, vale a reflexão de que o sucesso do projeto de um espaço público dependerá, cada vez mais, do enfrentamento de questões como estética e função, identidade local, usuários, preservação de valores e propostas de inovação.

\section{ReferênCIAS Bibliográficas}

ADESM - AGÊNCIA DE DESENVOLVIMENTO DE SANTA MARIA. Santa Maria em dados. Disponível em: https://santamariaemdados.com.br/1-aspectos-gerais/1-3-historia-domunicipio/. Acesso em: 15 dez. 2019.

AHMSM - ARQUIVO HISTÓRICO MUNICIPAL DE SANTA MARIA. Acervo digital do Arquivo Histórico de Santa Maria. Banco do Estado do Rio Grande do Sul [online]. [197-]. Disponível em: http://web2.santamaria.rs.gov.br/arquivohistorico/sistema_descricao_documental/ em: http://web2.santamaria.rs.gov.br/arquivohisto
index.php/b35r4;isad. Acesso em: 15 dez. 2019.

AHMSM - AROUIVO HISTÓRICO MUNICIPAL DE SANTA MARIA. Acervo digital do Arquivo Histórico de Santa Maria. Calçadão da Rua Dr. Bozano [online]. [entre 1979 e 1989]. Disponível em: http://web2.santamaria.rs.gov.br/arquivohistorico/sistema_descricao_ documental/index.php/1 mb3n;isad. Acesso em: 15 dez. 2019.

AHMSM - ARQUIVO HISTÓRICO MUNICIPAL DE SANTA MARIA. Acervo digital do Arquivo Histórico de Santa Maria. Calçadão da Rua Dr. Bozano [online]. [entre 1980 e 2000]. Disponível em: http://web2.santamaria.rs.gov.br/arquivohistorico/sistema_descricao_ documental/index.php/fjifh;isad. Acesso em: 15 dez. 2019.

AHMSM - ARQUIVO HISTÓRICO MUNICIPAL DE SANTA MARIA. Acervo digital do Arquivo Histórico de Santa Maria. Rua do Dr. Bozano [online]. [entre 1920 e 1960]. Disponível em: http://web2.santamaria.rs.gov.br/arquivohistorico/sistema_descricao_documental/index. php/s23ka;isad. Acesso em: 15 dez. 2019.

AHMSM - ARQUIVO HISTÓRICO MUNICIPAL DE SANTA MARIA. Acervo digital do Arquivo Histórico de Santa Maria. Vista aérea do Calçadão [online]. [entre 1979 e 1989b]. Disponíve em: < http://web2.santamaria.rs.gov.br/arquivohistorico/sistema_descricao_documental/ index.php/affqe;isad>. Acesso em: 15 dez. 2019.

AHMSM - ARQUIVO HISTÓRICO MUNICIPAL DE SANTA MARIA. Acervo digital do Arquivo Histórico de Santa Maria. Viaduto Evandro Behr [online]. [entre 1991 e 2000]. Disponível em: http.//web2 santamaria.rs.gov br/arquivohistorico/sistema_descricao_documental/ index.php/p9ytl;isad. Acesso em: 15 dez. 2019.

ALMEIDA, Luiz Gonzaga Binato de (resp. técnico); ATHAYDE, Valéria Ferraro (colaboração). Diagrama de pavimentação Setor 1. Via Exclusiva para Pedestres. Prancha 08. ANTUNES (desenho). Prefeitura Municipal de Santa Maria. Acervo do Instituto de Planejamento de Santa Maria. Ago. 1978

ALMEIDA, Luiz Gonzaga Binato de. Entrevista concedida a Filipe Bassan Marinho Maciel. Santa Maria, 06 jun. 2019. [Entrevista não publicada].

ASCHER, François. Os novos princípios do urbanismo. São Paulo: Romano Guerra, 2010.

BANCO CENTRAL DO BRASIL. Calculadora do cidadão [online]. [Correção de valores no período de janeiro de 1979 até dezembro de 2020]. Disponível em: https://www3.bcb.gov.br/ CALCIDADAO/publico/corrigirPorlndice.do?method=corrigirPorlndice. Acesso em: 19 jan. 2021 
BARRETO, José Gomes. O Calçadão. A Razão, Santa Maria, 5 jan. 1979, n. 70, p. 2. BELÉM, João. História do Município de Santa Maria - 1797-1933. Santa Maria: Edições UFSM, 1989.

BELTRÃO, Romeu. Cronologia histórica de Santa Maria e do extinto município de São Martinho: 1787 - 1930. 3. ed. Santa Maria: Ed. da UFSM, 2013.

BERMAN, Marshall. Tudo que é sólido desmancha no ar: a aventura da modernidade. São Paulo: Companhia das Letras, 1986

CALÇADÃo não agrada moradores da primeira quadra. A Razão, Santa Maria, 6 jan. 1979a, n. 71 , p. 16.

CALÇADÃo será entregue em março. A Razão, Santa Maria, 3 jan. 1979b, n. 68, p. 12

CALÇADÃO terá normas para uso público. A Razão, Santa Maria, 10 jun. 1979c, n. 197, p. 4.

CHARTIER, Roger. À beira da Falésia: a história entre certezas e inquietude. Porto Alegre: Editora da Universidade UFRGS, 2002.

CUNEGATTO, Thais. Etnografia na Rua da Praia: Um estudo antropológico sobre cotidiano memória e formas de sociabilidade no centro urbano porto-alegrense. 2009. 138 p. Dissertação (Mestrado em Antropologia Social) - Universidade Federal do Rio Grande do Sul, Porto Alegre, 2009

FONSECA, Fábio Luiz. Os calçadões e sua importância para a qualidade urbana na área central de Juiz de Fora. 2012. 162 f. Dissertação (Mestrado em Ambiente Construído) Universidade Federal de Juiz de Fora, Juiz de Fora, 2012.

GEHL, Jan; SVARRE, Birgitte Bundesen. A dimensão humana: uma abordagem sustentável do planejamento urbano. In: ANDRADE, Victor; LINKE, Clarisse Cunha (org.). Cidades de pedestres. 1. ed. Rio de Janeiro: Babilonia Cultural Editorial, 2017. p. 12-17.

JACOBS, Jane. Morte e vida de grandes cidades. 1. ed. São Paulo: Martins Fontes, 2000.

KEELER, Marian; BURKE, Bill. Fundamentos de projeto de edificações sustentáveis. Porto Alegre: Bookman, 2010.

KOSTOF, Spiro. The City Assembled: The Elements of Urban Form Through History. London: Thames \& Hudson Ltd., 1992.

MEHTA, Vikas. The street: a quintessential social public space. Oxon: Routledge, 2013.

NACTO - NATIONAL ASSOCIATION OF CITY TRANSPORTATION OFFICIALS. Guia global de desenho de ruas. São Paulo: SENAC SP, 2018.

O CALÇADÃO, entre os principais projetos. A Razão, Santa Maria, 31 jan. 1979, n. 91, p. 12

PARA onde vais, Saldanha? A Razão, Santa Maria, 17 jan. 1979, n. 79, n.p.

PEDESTRES nas obras do calçadão podem prejudicar desenvolvimento do trabalho. $A$ Razão, Santa Maria, 8 mar. 1979, n. 119, p. 4.

PESAVENTO, Sandra Jatahy. História \& História Cultural. Belo Horizonte: Autêntica, 2003.

PREFEITO inaugura "Calçadão" na abertura da semana de Santa Maria. A Razão, Santa

Maria, 10 maio $1979 a$, n. 171, p. 8.
PREFEITO inaugura com o "Calçadão" uma semana de festas para a cidade. A Razão, Santa Maria, 11 maio 1979b, n. 172, p. 1.

PROJECT FOR PUBLIC SPACES. What makes a successful place? 2020. Disponível em: https:// www.pps.org/article/grplacefeat. Acesso em: 23 set. 2020.

ROBBA, Fabio; MACEDO, Silvio Soares. Praças Brasileiras. 2. ed. São Paulo: Editora da Universidade de São Paulo، 2003.

RUBESTEIN, Harvey. Pedestrian Malls, Streetscapes, and Urban Spaces. New York: Wiley, 1992. SALVATORI, Elena. Arquitetura no Brasil: ensino e profissão. Arquitetura Revista, 4(2), 2008 p. 52-77. doi: 10.4013/arq.20082.06

SERPA, Angelo. O espaço público na cidade contemporânea. São Paulo: Contexto, 2007.

SOUZA, Herbert José de. Como se faz análise de conjuntura. Petrópolis: Vozes, 1984.

TV OVO. $1^{a}$ Quadra - Documentário [online]. 2009. (18m). Disponível em: https://youtu. be/Ondm2cuXvuA. Acesso em: 15 dez. 2019.

WILLE, José. História da primeira rua só de pedestres do Brasil em Curitiba [online]. 2018. (05m19s). Disponível em: https://youtu.be/hVOTNS91N2M. Acesso em: 15 dez. 2019

ZANATTA, Humberto Gabbi. O recreio na praça. A Razão, Santa Maria, 12 maio 1979, n. 173 , s.p.

Filipe Bassan Marinho Maciel

Universidade Federal do Rio Grande do Sul, Faculdade de Arquitetura. Rua Sarmento Leite, $320-5^{\circ}$ andar - Sala 510. Centro, Porto Alegre, RS. CEP 90050170

https://orcid.org/0000-0003-2202-2684

filipebassan@gmail.com

\section{Daniela Marzola Fialho}

Universidade Federal do Rio Grande do Sul, Faculdade de Arquitetura.

Rua Sarmento Leite, 320 - $5^{\circ}$ andar - Sala 510. Centro, Porto Alegre, RS.

CEP 90050170

https://orcid.org/0000-0002-0598-0306

dfialho.voy@terra.com.br

\section{Décio Rigatti}

Universidade Federal do Rio Grande do Sul, Faculdade de Arquitetura.

Rua Sarmento Leite, 320 - $5^{\circ}$ andar - Sala 510. Centro, Porto Alegre, RS.

CEP 90050170

https://orcid.org/0000-0002-4982-7821

driga2000@yahoo.com.br 
Nota do Editor:

Submetido em: 04/08/2020

Aprovado em: 20/01/2021

Revisão RMO 